\title{
Combining Individual and Organizational Capabilities: An Integrated Maturity Model for Ambidexterity
}

\author{
Rocco Xaver Richard Huber \\ FIM Research Center, University of \\ Augsburg \\ Project Group Business \& Infor- \\ mation Systems Engineering of the \\ Fraunhofer FIT \\ rocco.huber@fim-rc.de
}

\author{
Julia Renner \\ University of Augsburg \\ julia.katharina.renner@student.uni- \\ augsburg.de
}

\author{
Bastian Stahl \\ FIM Research Center, University of \\ Applied Sciences Augsburg \\ Project Group Business \& Infor- \\ mation Systems Engineering of the \\ Fraunhofer FIT \\ bastian.stahl@fim-rc.de
}

\begin{abstract}
Ambidexterity, the ability to simultaneously explore and exploit, has become a success factor to benefit from digitalization. Yet, especially for market incumbents, it is still challenging to develop needed capabilities for mastering ambidexterity. Existing work on ambidexterity lacks approaches for a holistic and combined perspective on the organization and the individual. Therefore, we develop an Individual and Organizational Ambidexterity Maturity Model (IOAMM) that provides holistic guidance for practitioners in approaching ambidexterity. Based on a literature review, our model consists of two dimensions for individual and organizational capabilities and is structured along five maturity stages. A preliminary evaluation with industry experts provides first feedback regarding comprehensiveness, consistency, and problem adequacy. Our IOAMM contributes to research by integrating two previously separate perspectives and extending both perspectives by a digital capability. For practitioners, it provides practical guidance for assessing and developing needed capabilities.
\end{abstract}

\section{Introduction}

In response to increasing global market pressure, especially through new players in established markets, companies must find new ways to stay competitive. Besides, digitalization disrupts entire industries. At the same time, digital technologies provide ample opportunities to leverage existing strengths and resources. On the one hand, companies need to become steadily more efficient to defend their market position. On the other hand, to defend their market position, companies should explore new impulses and embrace new digital trends to drive innovation $[4,35,43]$. Market incumbents, in particular, strive to develop capabilities that enable them to leverage their strengths (e.g., market position, product know-how, etc.) and simultaneously explore the possibilities of digital technologies for innovation $[27,55]$.

In this context, innovation can be understood as managing incremental (exploitation) and revolutionary (exploration) change at the same time. To overcome the tensions between exploration and exploitation, ambidexterity is essential and can be defined as the ability to manage both $[22,51]$. To master ambidexterity in an organizational context, however, it is necessary that the individuals who form the organization also possess specific capabilities that facilitate ambidexterity. Until now, in literature, capabilities for Organizational Ambidexterity (OA) and Individual Ambidexterity (IA) are discussed and developed in two separate streams [17, 18]. Over the last decades, OA and recently also IA have received considerable attention and have become intensively discussed topics $[1,21,38]$. Despite the advances in research, ambidexterity remains a significant challenge [51]. Research has already focused on paradoxes, antecedents, and effects of ambidexterity [1, 12, 25]. Yet, to master ambidexterity, an integrated consideration of more than one perspective is needed [12, 14]. Existing work demonstrates the benefits of integrating different perspectives to facilitate ambidexterity, e.g., the application of OA in the context of Business Process Management (BPM) [52]. Hafkesbrink et al. [17] already elaborated on organizational antecedents and individual aspects of ambidexterity in their seminal work. Nevertheless, an overarching structure that defines individual and organizational capabilities necessary to think and work ambidextrous still represents a missing link for guiding practitioners. Furthermore, existing literature addresses the interplay of ambidexterity and digitalization only to a limited extent $[6,16]$. To the best of our knowledge, there is no holistic maturity model (MM) that combines both perspectives and thus provides practical guidance for practitioners. As MMs are 
suitable and well-established artifacts for guiding transformations $[19,52]$, we develop a MM with the needed individual and organizational capabilities for ambidexterity. The developed IOAMM contributes by supporting managers in assessing organizational units and individuals regarding needed capabilities for ambidexterity. Based on the assessment, targeted measures can be identified to enhance ambidextrous maturity. Thereby, the IOAMM provides the needed structure, which can be supplemented with other strategy development approaches and capability development methods, tailored to each industry and organization's specific requirements.

This paper is organized as follows: First, we summarize the theoretical background of ambidexterity, along with a brief overview of OA, IA, MMs, and digitalization (section 2). Second, we outline our research design, which is based on Becker et al. [3] (section 3). Third, we present our IOAMM and relevant design decisions (section 4). Lastly, we make a preliminary evaluation of our model and its added value. We discuss the insights of our first interviews with four industry experts, which are of particular interest for practitioners (section 5). We conclude by stating the contribution of our results.

\section{Theoretical Background}

\subsection{Individual and Organizational Ambidexter- ity}

O'Reilly III and Tushman [43] define ambidexterity as the ability to assess whenever evolutionary (exploitation) or revolutionary (exploration) change is necessary and thus to master both innovation approaches at the same time. Exploration is understood as continuous innovation that symbolizes radical change and innovation of new products, services, and processes to achieve adaptability and growth $[38,41]$. In contrast, exploitation focuses on the current business through incremental improvements on the existing customer value (e.g., refinement of products and services) and operational execution [41].

Both innovation approaches compete for scarce resources. Too much resource allocation to either exploration or exploitation causes performance risks and negative impacts on the overall outcome. For example, if exploitation drives over exploration, the organization might miss new technical developments and risks obsolescence. If exploration drives over exploitation, the organization might take high risks while neglecting its core business [41].

As the mastery of exploitation and exploration, ambidexterity can be applied to both individuals and entire organizations. Existing research mainly focuses on the organizational side [18]. In general, three different modes of OA can be distinguished: structural [26, 41], sequential [53], and contextual [12]. Structural ambidexterity divides the organization into separate and mostly independent business units (e.g., digital labs/factories) for exploration and exploitation [41]. Sequential ambidextrous business units change between exploration and exploitation in sequences [34]. Contextual ambidexterity is executed when employees individually and the organization as a whole balance exploration and exploitation simultaneously $[7,12]$. However, research shows that the sole consideration of the organizational aspects does not cover the full applicational range of ambidexterity $[13,39]$. To achieve ambidexterity on a holistic organizational level, individuals need to balance exploitation and exploration in their work. IA, therefore, refers to the cognitive ability of an individual to adapt flexibly within dynamic environments by appropriately switching between exploration and exploitation [13]. For example, in the automotive sector, the same individual could be involved in innovation projects optimizing combustion engines (exploitation) while simultaneously being involved in other project settings searching for radical innovations such as alternative, renewable propulsion systems (exploration) [58].

\subsection{Maturity Models for Capabilities}

MMs have proven to be a suitable approach to show how capabilities evolve and map them onto their maturation stages regarding capability development. Because of their clearness and easy practicability for capability as-is assessment and step-wise development, MMs have become popular among researchers and especially among practitioners [5]. For example, in the BPM domain, MMs represent a popular and well-established tool to combine descriptive and prescriptive aspects [52].In this paper, we base our definitions on the multilevel cognitive model of Eggers and Kaplan [10] and use their hierarchy of concepts to clarify the subject matter. At the core, an ability can be described as the physical or mental power to do something [15]. Over time, abilities together form capabilities, which emerge from experience. Therefore, capabilities are less context-related [15] and enable to accomplish set goals [46]. A simple example of these concepts can be a sprinter: A sprinter has the general ability to sprint $100 \mathrm{~m}$. With growing experience and other abilities, the sprinter has the capability to accomplish set goals (e.g., optimizing on time or technique) while sprinting.

MMs are usually structured as matrices, contain a set of maturity stages, and a description of each stage's characteristics [47]. They assist in identifying organizational weak spots, assessing the as-is situation, and supporting the organization in developing the desired maturation of the defined target state $[3,5]$. MMs can be 
divided into three different types - staged, continuous, and focus area MMs [57]. While staged MMs assign practices to exactly one maturity stage, continuous MMs assign practices to all stages for developing different characteristics throughout the maturation path. Focus area MMs start with the practices and then develop the appropriate maturity stages [57]. Besides the three model types, every type then varies regarding their applicational purpose. Pöppelbuß and Röglinger [47] distinguish three application-specific purposes of use: descriptive, prescriptive, and comparative. Descriptive MMs analyze the organizations' as-is situation. MMs with prescriptive purpose support identifying maturity stages and give precise definitions of each stage. Further, a comparative purpose facilitates internal and external benchmarking based on data from a large number of evaluations [47].

\subsection{Digitalization and Ambidexterity}

Under digitalization, we understand the many sociotechnical phenomena and processes of adopting and using digital technologies in broader individual, organizational and social contexts [29]. To meet the demands and changes arising from digitalization, new capabilities must be developed at the individual and organizational level [44]. Therefore, a "digital capability" enables the organization to use digital technologies in such a way that they are aligned to business strategy for managing both existing business and new opportunities [46]. As a part of this capability, organizations need a more flexible Information Technology (IT) function capable of providing solutions that ease working ambidextrous (e.g., different tasks and teams) or developing innovative solutions upon digital technologies [16]. Simultaneously, individuals need to be open to digital technologies, the resulting changes, and learn, work, and innovate with digital alterations [49].

In Information Systems (IS) research, ambidexterity regarding the IT department earned great attention over the last years in the context of bimodal IT. Bimodal IT can be understood as managing two separate, coherent modes of IT - one aiming for stability, the other for agility $[2,16]$. Agility and stability can thereby be associated with exploration and exploitation. However, the effective implementation of these structures and the associated benefits can only be achieved with strong support from the organization, including the employees [16].

Thus, in the digital world, there is a reciprocal relationship between ambidexterity and digital capabilities. On the one hand, organizations need digital capabilities to explore and use digital technologies. On the other hand, ambidexterity enhances these digital capabilities.

\section{Research Design: Maturity Model devel- opment}

To develop the IOAMM, we follow the widely used 8-step procedure model of Becker et al. [3], as shown in Figure 1 . In this paper, we address Phases 1 to 4 (highlighted in grey), including a first pre-evaluation in the form of interviews with industry experts. Phases 5 to 8 are subject of further research.

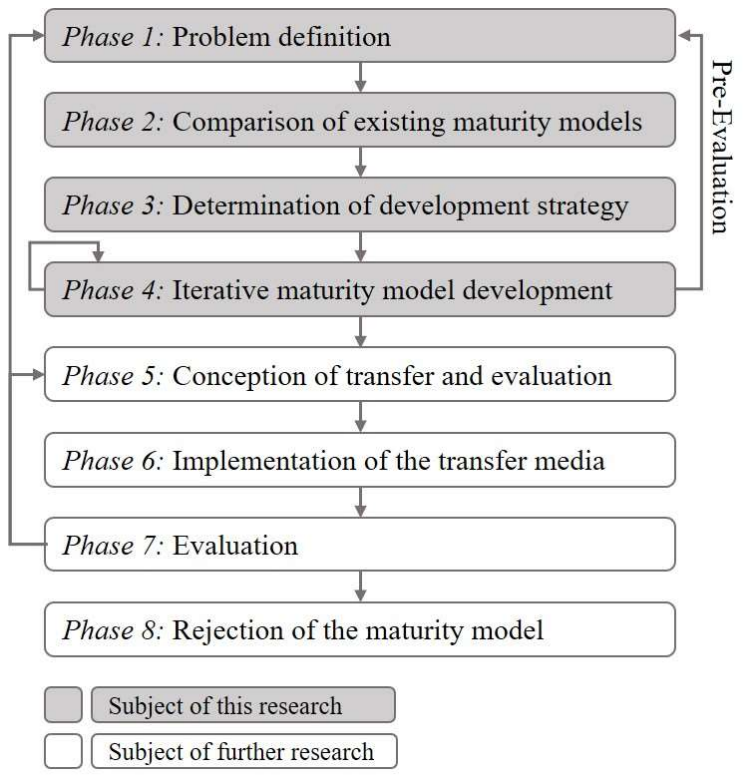

Figure 1. Procedure model based on Röglinger et al. [52]

Phase 1: The MM's problem needs to be defined, which was already outlined in the Introduction. Our MM addresses the difficulty of implementing ambidexterity out of an individual and organizational perspective (Section 4).

Phase 2: Existing MMs need to be identified and compared [3]. Based on the literature review and to the best of our knowledge, there are no MMs regarding ambidexterity's integrated application considering individual and organizational capabilities. Röglinger et al. [52] and Hafkesbrink et al. [17] consider both sides separately and build our model's basis.

Phase 3: Decisions regarding strategy and architecture are made at this point [3]. We decided to design a prescriptive and continuous MM as we develop the capabilities throughout the maturation process and provide guidance on their improvement. The MM is structured as a matrix with maturity stages on the horizontal and capability dimensions on the vertical axis.

Phase 4: Iterative MM development refers to the design and development process of the MM. To identify the dimensions for our two focus areas of the vertical 
axis, we conducted a literature review in Google Scholar and the databases ScienceDirect, EbscoHost, AISeL, and IEEE Xplore. For ambidexterity capabilities, we searched for organizational and individual capabilities that foster ambidextrous working. Further, we decided to divide both the individual and the organizational capabilities into five dimensions, which are mainly extracted from Hafkesbrink et al. [17] for individual capabilities, James and Jones [24], as well as Kortmann [28] for organizational capabilities.

Next, we developed a precise definition of every development stage for every dimension. According to the development process's iterative character, we conducted interviews with four industry experts as a pre-evaluation of the model's consistency, comprehensiveness, and problem adequacy[3].

Phase 5 to 8: After developing the model, it needs to be tested in a real-world context and evaluated for relevance and rigor, including validity and reliability [5]. Also, for guaranteeing broad applicability, the model has to be made available in a more general way to investigate its generalizability [3] (phase 5). Next, further evaluations and improvements on wider acceptance should be conducted (Phase 6, 7), and finally, a decision on the acceptance or the rejection of the model is going to be made (Phase 8). As mentioned before, those steps are not the object of this paper and subject to further research.

\section{Individual and Organizational Ambidex- terity Maturity Model}

In the following, we present our IOAMM with its overarching structure as the core part of this paper. In doing so, we describe pathbreaking design decisions and define the capability dimensions and maturity stages. Finally, we present the complete model.

Similar to the work of Röglinger et al. [52], dealing with the practical implications of OA in the BPM context, our model enables organizations to implement ambidexterity. Yet, as the importance of the individual for transforming into an ambidextrous organization received considerable attention in literature lately [14, 51], we cover both capability areas: organizational ambidexterity (OA) and individual ambidexterity (IA). Thereby, we understand an organization as a complex social system structured through independent subsystems [28]. These subsystems cover all subunits that have an external influence on the individual, implying the smallest organizational unit is at the team level, which can be used for the capability assessment. The maturity stages structure the developed IOAMM on the horizontal and the capability dimensions on the vertical axis. The latter is divided into two major parts: OA and IA capabilities. Both areas are then distinguished into sub-dimensions, which we elaborate on in the following and are defined in Tables $1 \& 2$. On the horizontal axis, we use five maturity stages ranging from novice to expert (i.e., Table 3) [9]. Throughout the maturation of each capability, we worked out specific characteristic features for each degree of maturity.

\subsection{Individual Capabilities}

In this work, we understand individual capabilities as capabilities that enable the individual to work ambidextrously. The individual capabilities mainly build on the work of Hafkesbrink et al. [17] as well as on Hafkesbrink and Schroll [18]. Both structure ambidexterity into organizational antecedents (i.e., work environment) and a perspective on the individual side. They define four categories of individual capabilities: professional, methodic, social, and personal. Despite the profound work of Hafkesbrink and Schroll [18], which in our perception is highly applicable and useful, the model leaves out the phenomenon of digitalization and how it implicates and fosters ambidextrous working. For this reason, we have added a digital capability dimension, building upon prior work addressing digital capabilities [44, 49]. Table 1 gives a brief definition of every capability dimension.

\section{Table 1. Individual capabilities}

\begin{tabular}{l|l}
\hline $\begin{array}{l}\text { Personal } \\
\text { Capabilities }\end{array}$ & $\begin{array}{l}\text { The ability of an individual to self- } \\
\text { organize, to learn, and to combine } \\
\text { knowledge [17]. }\end{array}$ \\
\hline $\begin{array}{l}\text { Digital } \\
\text { Capabilities }\end{array}$ & $\begin{array}{l}\text { The individual's openness for and } \\
\text { ability to learn and work with digi- } \\
\text { tal technologies and applications } \\
\text { [49]. }\end{array}$ \\
\hline $\begin{array}{l}\text { Professional } \\
\text { Capabilities }\end{array}$ & $\begin{array}{l}\text { The application of business-rele- } \\
\text { vant and industry-specific expert } \\
\text { knowledge [20]. }\end{array}$ \\
\hline Methodic & $\begin{array}{l}\text { Structured procedures to apply } \\
\text { knowledge, including the } \\
\text { knowledge about and application } \\
\text { of various methods and their com- } \\
\text { bination [18]. }\end{array}$ \\
\hline $\begin{array}{l}\text { Social } \\
\text { Capabilities }\end{array}$ & $\begin{array}{l}\text { Interactions in a business context } \\
\text { and the ability to interact with em- } \\
\text { pathy [12, 36]. }\end{array}$ \\
\hline
\end{tabular}

\subsection{Organizational Capabilities}

For structuring organizational capabilities, we build upon the work of Kortmann [26] and James and Jones [24]. James and Jones [24] published a review on theories of organizational structures and defined five organizational dimensions: centralization, configuration, formalization, specialization, and standardization. Similar 
dimensions are used by Kortmann [28]. In an OA's context, centralization and configuration can be represented by a joint dimension (i.e., structural capabilities) since both areas must be considered simultaneously.

The same applies to standardization, which we subsume under formalization capabilities. Important to add, as ambidexterity matures, the more formalization reflects precise and efficient structures, roles, and work processes. At the same time, it also leaves room for creative deviation and innovation. However, there can also be too much formalization. As the theory of Mintzberg [37] states - in the form of adhocracy, the organization needs to minimize the disadvantages of over formalized (i.e., bureaucratic) structures of standardization [45].

Specialization symbolizes an essential role within the innovation process of an organization. It is understood as labor division, meaning individuals are assigned to tasks and projects according to their capabilities. By establishing a transactive memory system, the collective encoding, storing, and retrieving of knowledge, the organization can more effectively combine and complement individuals' capabilities and assign them to the right tasks and projects [59].

Complementing the individual's digital capabilities, the organization also requires digital capabilities to foster ambidextrous thinking and working by providing suitable digital solutions, the needed access to digital technologies $[2,16,44]$, or the ability to align business and IT. Table 2 lists all organizational capability dimensions and their definitions.

Table 2. Organizational capabilities

\begin{tabular}{l|l}
\hline & $\begin{array}{l}\text { The applied structure within the or- } \\
\text { ganization, including the decision on } \\
\text { (de-) centralization. It is embodied } \\
\text { by the number of hierarchical levels } \\
\text { and roles' configuration, meaning } \\
\text { the vertical or horizontal span of } \\
\text { control and thus the range of author- } \\
\text { ity [48, 50]. }\end{array}$ \\
\hline $\begin{array}{l}\text { Formabilities } \\
\text { tion } \\
\text { Capabilities }\end{array}$ & $\begin{array}{l}\text { The degree of written role defini- } \\
\text { tions and role structures, including } \\
\text { the standardization of procedures } \\
\text { [50]. }\end{array}$ \\
\hline $\begin{array}{l}\text { Specializa- } \\
\text { tion }\end{array}$ & $\begin{array}{l}\text { The division of labor regarding tech- } \\
\text { nical depth or general width and the } \\
\text { collective allocation and recombina- } \\
\text { tion of knowledge [24]. }\end{array}$ \\
\hline $\begin{array}{l}\text { The organization's attitude toward } \\
\text { Capabilitities }\end{array}$ & $\begin{array}{l}\text { using digital technologies, meaning } \\
\text { recognizing digital needs and } \\
\text { providing suitable solutions [2, 16, } \\
\text { 44]. }\end{array}$ \\
\hline $\begin{array}{l}\text { Cultural } \\
\text { Capabilities }\end{array}$ & $\begin{array}{l}\text { The organization's collective values, } \\
\text { beliefs, and behaviors that foster }\end{array}$ \\
\hline
\end{tabular}

specific behavior, e.g., knowledgesharing, uncertainty tolerance, openness to challenge, and trust $[30,42]$.

\subsection{Maturity Stages}

For the IOAMM, we build upon the maturity stages on the vertical axis of Dreyfus and Dreyfus [9]. Their directed skill acquisition model is based on five stages describing individuals' development stages to acquire capabilities [9]. As the model aims at guiding the individuals' skill acquisition process, it is perfectly applicable to our individual side. Yet, for the organizational capabilities, we had to transfer the Dreyfus model to the organizational level. Thereby, we followed Röglinger et al. [52], who adapted Dreyfus on their organizational MM for ambidexterity. Our defined stages are now aligned according to OA and IA and based on the Dreyfus model. Table 3 shows a brief definition of each stage.

Table 3. Maturity stages

\begin{tabular}{l|l}
\hline \multirow{3}{*}{ Novice } & $\begin{array}{l}\text { Aware of ambidexterity, yet, has lim- } \\
\text { ited knowledge about it. To develop a } \\
\text { capability, first, the awareness of the } \\
\text { current state is needed. }\end{array}$ \\
\hline \multirow{5}{*}{$\begin{array}{l}\text { Advanced } \\
\text { Beginner }\end{array}$} & $\begin{array}{l}\text { With experience, recurrent patterns } \\
\text { can be identified, defined, and guide- } \\
\text { lines can be used to link them. New } \\
\text { strategies and changes in routines are } \\
\text { implemented to accomplish explora- } \\
\text { tional and exploitational objectives } \\
\text { simultaneously. }\end{array}$ \\
\hline Competent & $\begin{array}{l}\text { Gaining experience by learning how } \\
\text { to react to new situations. These expe- } \\
\text { riences are stored for similar situa- } \\
\text { tions in the future and evaluated to ad- } \\
\text { just routines if needed. }\end{array}$ \\
\hline Proficient & $\begin{array}{l}\text { The climax of the step-wise learning } \\
\text { is reached. The organization or the in- } \\
\text { dividual is able to react in an ambi- } \\
\text { dextrous manner intuitively. }\end{array}$ \\
\hline \multirow{5}{*}{ Expert } & $\begin{array}{l}\text { The step from imitation to intuition } \\
\text { and fully mastering the capability and } \\
\text { being able to teach it to others. }\end{array}$ \\
\hline
\end{tabular}

\subsection{IOAMM}

In the following, we present our complete IOAMM with the defined maturity levels for the aforementioned capability dimensions in Table 4. 


\section{Table 4. IOAMM}

\begin{tabular}{|c|c|c|c|c|c|c|}
\hline \multirow{6}{*}{ 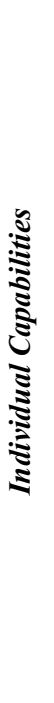 } & & Novice & Advanced Beginner & Competent & Proficient & Expert \\
\hline & $\begin{array}{c}\text { Per- } \\
\text { sonal }\end{array}$ & $\begin{array}{l}\text { Abilities such as rational and creative } \\
\text { thinking are available but not used to } \\
\text { accomplish explorative or exploitation } \\
\text { tasks [11]. }\end{array}$ & $\begin{array}{l}\text { The individual's self-organization and learn- } \\
\text { ing abilities are analyzed, trained, and } \\
\text { aligned for ambidextrous working [31]. }\end{array}$ & $\begin{array}{l}\text { The individual internalizes new routines and } \\
\text { working habits to become better at performing } \\
\text { ambidextrous tasks. }\end{array}$ & $\begin{array}{l}\text { The individual organizes intuitively in an } \\
\text { ambidextrous manner, and skillfully com- } \\
\text { bines his/her knowledge over different ar- } \\
\text { eas [ } 88 \text { ]. }\end{array}$ & $\begin{array}{l}\text { The individual can instruct others in } \\
\text { acquiring and using abilities for ambi- } \\
\text { dextrous working. }\end{array}$ \\
\hline & Digital & $\begin{array}{l}\text { The individual disposes general } \\
\text { knowledge of digital technologies and } \\
\text { solutions, but the use is limited to spe- } \\
\text { cific tasks and cannot be applied to } \\
\text { other areas }[56] \text {. }\end{array}$ & $\begin{array}{l}\text { The individual is incentivized to learn, un- } \\
\text { derstand, and use digital technologies to fos- } \\
\text { ter ambidextrous thinking and working. }\end{array}$ & $\begin{array}{l}\text { Through practice and experience, the newly } \\
\text { learned digital solutions, features, and rules be- } \\
\text { come routines [4]. The individual increasingly } \\
\text { usses digital technologies to improve hishlher rou- } \\
\text { tines and innovate new solutions. }\end{array}$ & $\begin{array}{l}\text { Openness towards new enhancements and } \\
\text { the ability to use various digital technolo- } \\
\text { gies in different fields are established } \\
\text { [56]. The individual increasingly looks for } \\
\text { new digital technologies and how to bene- } \\
\text { fit from them in hisher field of work. }\end{array}$ & $\begin{array}{l}\text { Individuals can teach and instruct oth- } \\
\text { ers in using digital technologies for } \\
\text { ambidexterity and are capable of re- } \\
\text { combining different digital technolo- } \\
\text { gies and features. }\end{array}$ \\
\hline & $\begin{array}{l}\text { Profes- } \\
\text { sional }\end{array}$ & $\begin{array}{l}\text { Professional expertise exists, but there } \\
\text { is few internal or external exchange. } \\
\text { The individual does not know when } \\
\text { evolutionary and revolutionary change } \\
\text { is necessary [43]. }\end{array}$ & $\begin{array}{l}\text { The individual learns to be open-minded, } \\
\text { connects knowledge sources [31], and begins } \\
\text { to use his/her expert knowledge for exploita- } \\
\text { tive and explorative tasks mindfully. }\end{array}$ & $\begin{array}{l}\text { The individual can choose evolutionary and rev- } \\
\text { olutionary change when appropriate. Collabora- } \\
\text { tions with different teams and fields of expertise } \\
\text { are tested, assessed, and the results are stored } \\
\text { for future reference [12]. }\end{array}$ & $\begin{array}{l}\text { The individual makes use of newly } \\
\text { achieved and combined knowledge }[40] \text {. } \\
\text { The recognition of evolutionary or revolu- } \\
\text { tionary tasks becomes more and more in- } \\
\text { tuitive. }\end{array}$ & $\begin{array}{l}\text { The individual masters evolutionary } \\
\text { and revolutionary routines and tasks ef- } \\
\text { ficiently and can promote hish/ere ex- } \\
\text { pertise for diverse tasks and projects. }\end{array}$ \\
\hline & $\begin{array}{l}\text { Me- } \\
\text { thodic }\end{array}$ & $\begin{array}{l}\text { Methodological knowledge exists but } \\
\text { is not focused on or used for IA. }\end{array}$ & $\begin{array}{l}\text { Newly acquired and existing methods are } \\
\text { evaluated and adjusted to ambidextrous } \\
\text { needs [54]. }\end{array}$ & $\begin{array}{l}\text { Experiences from different situations are stored } \\
\text { for unture reference and support the implemen- } \\
\text { tation of methods for ambidextrous working } \\
\text { [12]. The individual can identify missing meth- } \\
\text { odological knowledge for mastering ambidex- } \\
\text { terity in hisher tasks and routines. }\end{array}$ & $\begin{array}{l}\text { Newly acquired methods are mastered and } \\
\text { used intuitively when needed [54]. The in- } \\
\text { dividual in sow able to combine different } \\
\text { methods over various areas [39]. }\end{array}$ & $\begin{array}{l}\text { The individual is capable of teaching } \\
\text { methods for improving ambidextrous } \\
\text { working and continuously recombines } \\
\text { methods for domain-specific problems. }\end{array}$ \\
\hline & Social & $\begin{array}{l}\text { According to the explorative or exploi- } \\
\text { tative task, the individual is very lim- } \\
\text { ited in adapting hish her social skills } \\
\text { [26]. E.g., when working in several } \\
\text { cross-functional teams by not swith- } \\
\text { ing the rolo according to the task and } \\
\text { situation. }\end{array}$ & $\begin{array}{l}\text { The individual becomes aware that social } \\
\text { norms and strategies are required for ambi- } \\
\text { dextrous working [34]. Learnings are gained } \\
\text { by new routines, working in cross-functional } \\
\text { teams [33], or being part of different teams. }\end{array}$ & $\begin{array}{l}\text { The individual forms social strategies to im- } \\
\text { prove social interaction and continuously re- } \\
\text { flects his/her social norms. Switching the be- } \\
\text { havior and way of interacting with others ac- } \\
\text { cording to the task and team becomes intui- } \\
\text { tively. }\end{array}$ & $\begin{array}{l}\text { Individuals internalize social norms and } \\
\text { strategies for effective collaboration n33]. } \\
\text { Consideration and a reflective attitude are } \\
\text { valued and intuitively integrated into } \\
\text { working processes. }\end{array}$ & $\begin{array}{l}\text { An ambidextrc } \\
\text { commonly sup } \\
\text { and communic }\end{array}$ \\
\hline \multirow{5}{*}{ 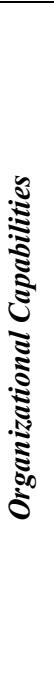 } & $\begin{array}{l}\text { Struc- } \\
\text { tural }\end{array}$ & $\begin{array}{l}\text { The organizational structure is not tai- } \\
\text { lored to foster ambidexterity. For ex- } \\
\text { ample, complex decision processes hin- } \\
\text { der exploration. }\end{array}$ & $\begin{array}{l}\text { Based on appropriate models, strategies, and } \\
\text { deliberations on structural forms to foster } \\
\text { ambidexterity are made, i.e., the number of } \\
\text { hierarchical levels and the range of authority } \\
{[28,48,53] \text {. }}\end{array}$ & $\begin{array}{l}\text { Fundamental decisions on the vertical or hori- } \\
\text { zontal structure and the range of authority are } \\
\text { made and implemented [484]. Employees adapt } \\
\text { to new structures and work modes. }\end{array}$ & $\begin{array}{l}\text { Experience forms new stru } \\
\text { cesses into intuitive routine } \\
\text { such as decision processes, } \\
\text { the new structures }[50] \text {. }\end{array}$ & $\begin{array}{l}\text { The organization } \\
\text { provement based } \\
\text { to others and conti } \\
\text { organizational stru }\end{array}$ \\
\hline & $\begin{array}{l}\text { Formal- } \\
\text { ization }\end{array}$ & $\begin{array}{l}\text { Role definitions and understanding } \\
\text { align with the dedicated needs of single } \\
\text { tasks but do not address the objective } \\
\text { of enhancing ambidexterity. }\end{array}$ & $\begin{array}{l}\text { Established role definitions and their under- } \\
\text { standing become challenged and adapted un- } \\
\text { der the aspect of ambidexterity [50]. }\end{array}$ & $\begin{array}{l}\text { Role definitions and understanding are adapted } \\
\text { to improve ambidextrous working. Their adjust- } \\
\text { ment is communicated within the organization } \\
\text { [50]. }\end{array}$ & $\begin{array}{l}\text { New roles become standard [28], and a } \\
\text { continuous search for the best level of for- } \\
\text { malization is becoming a routine [45]. }\end{array}$ & $\begin{array}{l}\text { Roles are both internalized and still } \\
\text { adaptable. The organization can teach } \\
\text { its formalization enhancements to oth- } \\
\text { ers. }\end{array}$ \\
\hline & $\begin{array}{l}\text { Special- } \\
\text { ization }\end{array}$ & $\begin{array}{l}\text { The division of labor and allocation of } \\
\text { knowledge does not, or only to a lim- } \\
\text { ited extent, support the mindful use of } \\
\text { expertise regarding ambidexterity [23]. }\end{array}$ & $\begin{array}{l}\text { Establishing a transactive memory system } \\
\text { enables linking individual know-how at an } \\
\text { organizational level to support the mindful } \\
\text { use of expertise for either exploitative or ex- } \\
\text { plorative tasks [59]. }\end{array}$ & $\begin{array}{l}\text { First evaluations, corrections, and reallocations } \\
\text { of the transactive memory systems are made. } \\
\text { The mapping of know-how and task require- } \\
\text { ments improves. }\end{array}$ & $\begin{array}{l}\text { The practical and mindful division of la- } \\
\text { bor and reallocation of knowledge fosters } \\
\text { ambidextrous working [23]. }\end{array}$ & $\begin{array}{l}\text { The organization continually improves } \\
\text { its mapping of know-how to tasks and } \\
\text { can forward this knowledge to others. }\end{array}$ \\
\hline & Digital & $\begin{array}{l}\text { Digital solutions are planned and exe- } \\
\text { cuted without addressing ambidextrous } \\
\text { requirements [56]. }\end{array}$ & $\begin{array}{l}\text { Requirements for ambidextrous working are } \\
\text { assessed and integrated into the IT strategy. }\end{array}$ & $\begin{array}{l}\text { The organization repeatedly changes and adjusts } \\
\text { digital solutions, such as collaboration plat- } \\
\text { forms, to serve agility and reliability simultane- } \\
\text { ously }[2,4] \text {. }\end{array}$ & $\begin{array}{l}\text { Continuous improvement of solutions to } \\
\text { foster ambidexterity becomes routine [32]. } \\
\text { New digital technologies are identified } \\
\text { and assessed for ambidextrous needs. }\end{array}$ & $\begin{array}{l}\text { The organization suitable digital solu- } \\
\text { tions to efficiently work in different } \\
\text { teams and switch between explorative } \\
\text { and exploitative tasks }[2,32] \text {. The or- } \\
\text { ganization can teach these learnings or } \\
\text { provide digital solutions to others. }\end{array}$ \\
\hline & Cultural & $\begin{array}{l}\text { A culture for ambidextrous working } \\
\text { does not exist. Essential values for am- } \\
\text { bidexterity are not integrated into the } \\
\text { organization's ways of working. }\end{array}$ & $\begin{array}{l}\text { Along with changes in structure, formaliza- } \\
\text { tion, and specializazition, a absis of values for } \\
\text { ambidextrous thinking and working is estab- } \\
\text { lished [30]. }\end{array}$ & $\begin{array}{l}\text { A culture with values of knowledge-sharing, } \\
\text { tolerance, and trust enables changes thinking, } \\
\text { collaborating, and deciding ambidextrously. }\end{array}$ & $\begin{array}{l}\text { The organization follows a strong culture } \\
\text { for ambidextrous thinking and working; } \\
\text { corresponding values are respected and } \\
\text { continuously challenged [30]. }\end{array}$ & $\begin{array}{l}\text { The organizational culture is indicative } \\
\text { of the success in thinking and working } \\
\text { ambidextrous and stimulates others to } \\
\text { adopt. }\end{array}$ \\
\hline
\end{tabular}




\section{Pre-Evaluation}

To capture initial feedback from practitioners and critically review the structure, applicability, and added value of the model, we conducted a pre-evaluation [3]. As the model aims at providing practitioners with guidance and structure when assessing and developing ambidexterity within their company, we conducted four semi-structured interviews with industry experts. We pre-evaluated our MM in a naturalistic setting according to the proposed evaluation criteria of Becker et al. [3]: comprehensiveness, problem adequacy, and consistency.

When selecting the interview partners, we paid attention to the requirements of holding a senior management position within their company, having vast experience in innovation management, and a strong focus on IT and digital transformation projects. At least two authors supervised all interviews, the evaluation criteria were explicitly addressed, and the interviews were digitally recorded. Interview partner 1 is the CFO of a Swiss insurance organization, partner 2 is an innovation manager in a German corporate and investment bank, partner 3 is the head of IT at a leading German manufacturer for medical products, and interview partner 4 is a team leader in an internationally acting engineering supplier in Germany.

Regarding comprehensiveness, all interview partners considered the MM's general design as suitable and appreciated the integration of an organizational and individual perspective as both are relevant in a real-world context. The chosen dimensions were approved as well-defined and practically useful. Yet, for the dimensions, interviewee 1 missed organizational culture as an essential aspect of becoming an ambidextrous organization. Interviewee 3 confirmed that organizational culture is vital in establishing ambidexterity. Nevertheless, culture is also shaped by developing the organizational structure and the formalization of roles. Based on the interviewees' feedback, the author team decided to add it as a dimension after intensively discussing and challenging it with fellow scholars' findings and publications [30, 42].

Further, interviewee 2 pointed out that empathy is an essential driver for innovation. Especially in teams, every individual needs to dispose of empathic social capabilities to foster collective innovation. Under this aspect, individual social capabilities were challenged and complemented.

Problem adequacy, the agreement that the designed model significantly supports in implementing ambidexterity, was confirmed by all industry experts. Thus, they emphasized that the IOAMM is of great help when transforming the organization toward ambidexterity. Some interviewees have already had experience using MMs for capability development, e.g., using it for capability assessments for manager promotions. Interviewee 1 and 3 also stressed that the IAOMM is rather suitable for initiating the right thoughts at the right time than for a 1:1 use and implementation in their organization. The model does not have to be applied to the whole organization, which was by all interviewees considered a reasonably complex and challenging task, but rather to teams and departments.

The consistency of the MM was generally agreed on and led to no significant changes in the model.

\section{Contribution and Limitations}

Emerging digital technologies have significant effects on companies, their value proposition, and their processes and routines. To distinguish themselves and stay competitive, especially market incumbents must find ways to build upon their strengths (e.g., product know-how, human resources) and utilize emerging digital technologies. Ambidexterity, the ability to simultaneously explore and exploit, is vital in staying innovative and competitive. Nevertheless, the structured development of relevant capabilities and the accompanied transformation process still poses a significant challenge to most established companies.

With the developed IOAMM, we address the increasing importance of understanding and implementing ambidexterity to master digitalization. Following the development process of Becker et al. [3], our MM guides organizations in becoming ambidextrous at a sustainable and long-term level. The presented IOAMM consists of ten capability dimensions that mature over five maturity levels. Thereby, the presented IOAMM creates an overarching structure that incorporates both the individual and organizational perspectives on relevant capabilities. As digitalization plays an essential role for individuals and organizations, we added a digital capability on both sides.

The IOAMM contributes to practice by supporting managers in assessing organizational units and individuals regarding needed capabilities for ambidexterity. Based on the assessment, targeted measures can be identified to enhance ambidextrous maturity. The conducted pre-evaluation of our model with four very experienced industry experts confirmed the added value of the model in practice and supported our approach's problem adequacy. Nevertheless, the generality of the IOAMM leaves room for adjustments to the particular circumstances (e.g., industry) and the needs of every organization and manager.

As for the theoretical contribution, our MM extents the descriptive and prescriptive body of knowledge. Combining the individual and organizational 
perspective into one model merges two separate literature streams and provides a holistic perspective. Necessary to add and stressed by the interview experts, the organizational side does not only cover the whole organization's perspective. It can also address sub-units such as departments or teams, which broadens the model's applicability.

With the IOAMM, we created the first version of this model, which is of interest for future research as it suffers certain limitations. First, MMs are often criticized by practitioners because of its generality and lack of precision. Similar aspects were mentioned in our interviews. The clear differentiation between the five maturity stages is challenging as there are no clear boundaries. Therefore, future work could conduct indepth structured literature research to specify further and distinguish the capability stages. Real-world instantiations could display a promising approach to test and complement the IOAMM accompanied by examining the model in a real world-context, e.g., with a comprehensive case study.

Second, as there is no real-word demonstration yet, there is no proof of the model's impact on firm performance when working ambidextrous. With the expert interviews, we can only prove the need and acceptance, but the implications on performance need to be carefully investigated for broader application.

Third, the evaluation with four industry experts is likewise not enough for substantial evaluation and feedback on the model. A broader set of industry experts from different industries and organizational functions would enrich the model development. In addition to interviews, MM-specific evaluation methods, as card sorting, would help to further iteratively develop the model. Yet, a MM always indicates a call for action [3] as environmental and business circumstances regularly change and, therefore, the content requires constant adjustment.

\section{References}

[1] Andriopoulos, C. and M.W. Lewis, "Exploitation-exploration tensions and organizational ambidexterity: Managing paradoxes of innovation", Organization Science, 20(4), 2009, pp. 696-717.

[2] Badr, N.G., "Enabling Bimodal IT: Practices for Improving Organizational Ambidexterity for Successful Innovation Integration", in 24th Americas Conference on Information Systems Sciences. 2018: New Orleans.

[3] Becker, J., R. Knackstedt, and J. Pöppelbuß, "Developing maturity models for IT management", Business \& Information Systems Engineering, 1(3), 2009, pp. 213-222.

[4] Branstetter, L.G., B. Glennon, and J.B. Jensen, "The IT Revolution and the Globalization of R\&D", Innovation Policy and the Economy, 19(1), 2019, pp. 1-37.
[5] Bruin, T. de, M. Rosemann, R. Freeze, and U. Kulkarni, "Understanding the main phases of developing a maturity assessment model", in 16th Australasian Conference on Information Systems (ACIS). 2005: Sydney.

[6] Cenamor, J., V. Parida, and J. Wincent, "How entrepreneurial SMEs compete through digital platforms: The roles of digital platform capability, network capability and ambidexterity", Journal of Business Research, 100, 2019, pp. 196-206.

[7] Clercq, D. de, N. Thongpapanl, and D. Dimov, "Contextual ambidexterity in SMEs: the roles of internal and external rivalry", Small Business Economics, 42(1), 2014, pp. 191-205.

[8] Collins, C.J. and K.G. Smith, "Knowledge exchange and combination: The role of human resource practices in the performance of high-technology firms", Academy of Management Journal, 49(3), 2006, pp. 544-560.

[9] Dreyfus, S.E. and H.L. Dreyfus, A five-stage model of the mental activities involved in directed skill acquisition, California Univ Berkeley Operations Research Center, 1980.

[10] Eggers, J.P. and S. Kaplan, "Cognition and capabilities: A multi-level perspective", Academy of Management Annals, 7(1), 2013, pp. 295-340.

[11] Fong, C.T., "The effects of emotional ambivalence on creativity", Academy of Management Journal, 49(5), 2006, pp. 1016-1030.

[12] Gibson, C.B. and J. Birkinshaw, "The antecedents, consequences, and mediating role of organizational ambidexterity", Academy of Management Journal, 47(2), 2004, pp. 209-226.

[13] Good, D. and E.J. Michel, "Individual ambidexterity: Exploring and exploiting in dynamic contexts", The Journal of Psychology, 147(5), 2013, pp. 435-453.

[14] Güttel, W.H., S.W. Konlechner, and J.K. Trede, "Standardized individuality versus individualized standardization: the role of the context in structurally ambidextrous organizations", Review of Managerial Science, 9(2), 2015, pp. 261-284.

[15] Hafeez, K., Y. Zhang, and N. Malak, "Core competence for sustainable competitive advantage: a structured methodology for identifying core competence", IEEE Transactions on Engineering Management, 49(1), 2002, pp. 28-35.

[16] Haffke, I., B. Kalgovas, and A. Benlian, "The transformative role of bimodal IT in an era of digital business", in 50th Hawaii International Conference on System Sciences (HICSS). 2017: Hawaii.

[17] Hafkesbrink, J., C. Bachem, and D. Kulenovic, "Contextual Ambidexterity and Individual Competencies for Exploration and Exploitation in Small and Medium sized Enterprises-Empirical Results from Case Studies in the German New Media Industry", in ISPIM Conference Proceedings. 2012: Barcelona. 
[18] Hafkesbrink, J. and M. Schroll, "Ambidextrous organizational and individual competencies in open innovation: the dawn of a new research agenda", Journal of Innovation Management, 2(1), 2014, pp. 9-46.

[19] Hammer, M., "The process audit", Harvard Business Review, 85(4), 2007, p. 111.

[20] Harzallah, M., G. Berio, and F. Vernadat, "Analysis and modeling of individual competencies: toward better management of human resources", IEEE Transactions on Systems, Man, and Cybernetics-Part A: Systems and Humans, 36(1), 2005, pp. 187-207.

[21] He, X., X. Wu, Y. Zhao, and D. Croasdell, "Dynamic Capability, Ambidexterity, Social Network - Empirical Evidence from SMEs in China", in 53rd Hawaii International Conference on System Sciences (HICSS). 2020: Hawaii.

[22] He, Z.-L. and P.-K. Wong, "Exploration vs. exploitation: An empirical test of the ambidexterity hypothesis", Organization Science, 15(4), 2004, pp. 481-494.

[23] Hendriks, M.H.A., B. Voeten, and L. Kroep, "Human resource allocation in a multi-project $\mathrm{R} \& \mathrm{D}$ environment: resource capacity allocation and project portfolio planning in practice", International Journal of Project Management, 17(3), 1999, pp. 181-188.

[24] James, L.R. and A.P. Jones, "Organizational structure: A review of structural dimensions and their conceptual relationships with individual attitudes and behavior", Organizational Behavior and Human Performance, 16(1), 1976, pp. $74-113$.

[25] Jansen, J.J.P., Van Den Bosch, Frans AJ, and H.W. Volberda, "Exploratory innovation, exploitative innovation, and performance: Effects of organizational antecedents and environmental moderators", Management Science, 52(11), 2006, pp. 1661-1674.

[26] Jansen, J.J.P., D. Vera, and M. Crossan, "Strategic leadership for exploration and exploitation: The moderating role of environmental dynamism", The Leadership Quarterly, 20(1), 2009, pp. 5-18.

[27] Kaulio, M., K. Thorén, and R. Rohrbeck, "Double ambidexterity: How a Telco incumbent used business-model and technology innovations to successfully respond to three major disruptions", Creativity and Innovation Management, 26(4), 2017, pp. 339-352.

[28] Kortmann, S., The relationship between organizational structure and organizational ambidexterity: A comparison between manufacturing and service firms, Springer Science \& Business Media, 2012

[29] Legner, C., T. Eymann, T. Hess, C. Matt, T. Böhmann, P. Drews, A. Mädche, N. Urbach, and F. Ahlemann, "Digitalization: Opportunity and Challenge for the Business and Information Systems Engineering Community", Business \& Information Systems Engineering, 59(4), 2017, pp. 301308.

[30] Lin, H.-E. and E.F. McDonough, "Investigating the Role of Leadership and Organizational Culture in Fostering
Innovation Ambidexterity", IEEE Transactions on Engineering Management, 58(3), 2011, pp. 497-509.

[31] Lin, H.-E., E.F. McDonough, S.-J. Lin, and C.Y.-Y. Lin, "Managing the Exploitation/Exploration Paradox: The Role of a Learning Capability and Innovation Ambidexterity", Journal of Product Innovation Management, 30(2), 2013, pp. 262-278

[32] Liu, H., W. Ke, K.K. Wei, and Z. Hua, "The impact of IT capabilities on firm performance: The mediating roles of absorptive capacity and supply chain agility", Decision Support Systems, 54(3), 2013, pp. 1452-1462.

[33] Lovelace, K., D.L. Shapiro, and L.R. Weingart, "Maximizing cross-functional new product teams' innovativeness and constraint adherence: A conflict communications perspective", Academy of Management Journal, 44(4), 2001, pp. 779-793.

[34] Lubatkin, M.H., Z. Simsek, Y. Ling, and J.F. Veiga, "Ambidexterity and performance in small-to medium-sized firms: The pivotal role of top management team behavioral integration", Journal of Management, 32(5), 2006, pp. 646672 .

[35] March, J.G., "Exploration and exploitation in organizational learning", Organization Science, 2(1), 1991, pp. 71-87.

[36] McDonagh, D. and J. Thomas, "Rethinking design thinking: Empathy supporting innovation", Australasian Medical Journal, 3(8), 2010, pp. 458-464.

[37] Mintzberg, H., "The Structuring of Organizations: A Synthesis of the Research.", Historical Research Reference in Entrepreneurship, 1979.

[38] Mirow, C., K. Hoeizle, and H.G. Gmuenden, "The Ambidextrous Organisation in Practice: Barriers to Innovation within Research and Development", in Academy of Management Proceedings. 2008

[39] Mom, T.J.M., Van Den Bosch, Frans AJ, and H.W. Volberda, "Understanding variation in managers' ambidexterity: Investigating direct and interaction effects of formal structural and personal coordination mechanisms", Organization Science, 20(4), 2009, pp. 812-828.

[40] Mompó, R., "Integrating Individual Competencies to Form Organisational Capability: Towards a More Holistic Approach in Aeronautical Industry", in 8th International Conference "Supply on the Wings". 2013: Frankfurt.

[41] O'Reilly III, C.A. and M.L. Tushman, "Ambidexterity as a dynamic capability: Resolving the innovator's dilemma", Research in Organizational Behavior, 28, 2008, pp. 185-206.

[42] O'Reilly III, C.A., J. Chatman, and D.F. Caldwell, "People and organizational culture: A profile comparison approach to assessing person-organization fit", Academy of Management Journal, 34(3), 1991, pp. 487-516.

[43] O'Reilly III, C.A. and M.L. Tushman, "Ambidextrous organizations: Managing evolutionary and revolutionary 
change", California Management Review, 38(4), 1996, pp. 8-29.

[44] Osmundsen, K.S., "Competences for Digital Transformation: Insights from the Norwegian Energy Sector", in 53rd Hawaii International Conference on System Sciences (HICSS). 2020: Hawaii.

[45] Parikh, M., "Move over Mintzberg, let adhocracy give way to ambidexterity", Management Decision, 2016.

[46] Peppard, J. and J. Ward, "Beyond strategic information systems: towards an IS capability", The Journal of Strategic Information Systems, 13(2), 2004, pp. 167-194.

[47] Pöppelbuß, J. and M. Röglinger, "What makes a useful maturity model? A framework of general design principles for maturity models and its demonstration in business process management", in 19th European Conference on Information Systems (ECIS). 2011: Helsinki.

[48] Porter, L.W. and E.E. Lawler, "Properties of organization structure in relation to job attitudes and job behavior", Psychological Bulletin, 64(1), 1965, p. 23.

[49] Prifti, L., M. Knigge, H. Kienegger, and H. Krcmar, "A Competency Model for" Industrie 4.0" Employees", in 13th International Conference on Wirtschaftsinformatik. 2017: St. Gallen.

[50] Pugh, D.S., D.J. Hickson, C.R. Hinings, and C. Turner, "Dimensions of organization structure", Administrative Science Quarterly, 1968, pp. 65-105.

[51] Raisch, S., J. Birkinshaw, G. Probst, and M.L. Tushman, "Organizational ambidexterity: Balancing exploitation and exploration for sustained performance", Organization Science, 20(4), 2009, pp. 685-695.

[52] Röglinger, M., L. Schwindenhammer, and K. Stezl, "How to put organizational ambidexterity into practice-towards a maturity model", in 16th International Conference on Business Process Management. 2018: Sydney.

[53] Siggelkow, N. and D.A. Levinthal, "Temporarily divide to conquer: Centralized, decentralized, and reintegrated organizational approaches to exploration and adaptation", Organization Science, 14(6), 2003, pp. 650-669.

[54] Smith, W.K. and M.L. Tushman, "Managing strategic contradictions: A top management model for managing innovation streams", Organization Science, 16(5), 2005, pp. 522-536.

[55] Svahn, F., L. Mathiassen, and R. Lindgren, "Embracing Digital Innovation in Incumbent Firms: How Volvo Cars Managed Competing Concerns", MIS quarterly, 41(1), 2017, pp. 239-253.

[56] Tou, Y., C. Watanabe, K. Moriya, V. Vurpillat, and P. Neittaanmäki, "A new concept of R\&D in neo open innovation: transformation of R\&D triggered by Amazon", International Journal of Managing Information Technology, 11(1), 2019.
[57] van Steenbergen, M., R. Bos, S. Brinkkemper, I. van de Weerd, and W. Bekkers, eds., The design of focus area maturity models, Springer, 2010.

[58] Visser, M. de, P. de Weerd-Nederhof, D. Faems, M. Song, B. van Looy, and K. Visscher, "Structural ambidexterity in NPD processes: A firm-level assessment of the impact of differentiated structures on innovation performance", Technovation, 30(5-6), 2010, pp. 291-299.

[59] Zhang, Z.-X., P.S. Hempel, Y.-L. Han, and D. Tjosvold, "Transactive memory system links work team characteristics and performance", Journal of Applied Psychology, 92(6), 2007, p. 1722. 